\title{
Mutagenic Induction of Yield Contributing Traits in of Soybean (Glycine max (L.) Merrill) with Gamma Irradiation and EMS
}

\author{
H. V. Kalpande, S. B. Borgaonkar* and S. K. Chavan \\ Department of Agril. Botany, Vasantrao Naik Marathwada Krishi Vidyapeeth, \\ Parbhani, (Maharashtra), India
}

\section{A B S T R A C T}

\begin{tabular}{|l|}
\hline Ke y w o r d s \\
Polygenic \\
variability, Gamma \\
rays, Mutagenic \\
effects, Soybean, \\
Yield traits
\end{tabular}

The effects of different doses of gamma rays $(0,10,20$ and $30 \mathrm{kR})$ and ethyl methane sulphonate (EMS) $(0.4,0.6$ and $0.8 \%)$ on mutagenic induced in soybean cv. JS 97-52, MAUS-47 and JS 97-52 x MAUS-47 were investigated. The sensitivity response of soybean to gamma radiation and EMS was determined based on seed germination, plant survival and growth reduction in the $\mathrm{M}_{1}, \mathrm{~F}_{1} \mathrm{M}_{1}$ generation. In the present investigation, variability induced by gamma rays and EMS for ten quantitative traits of soybean was studied. A significant shift in mean values in the positive direction over control was observed for most of the quantitative traits in all the populations, while in some cases particularly at higher doses; the decrease in mean values was noticed. The estimates of coefficient of variability for all the characters were high in all the mutagenic treatments. The high coefficient of variability was also accompanied by moderate to high heritability and genetic advance as percent of mean for different characters in various mutagenic treatments. Therefore, phenotypic selection for different characters will be effective in the treated population.

\section{Introduction}

Soybean (Glycine max L. Merrill) has become the miracle crop of the $21^{\text {st }}$ century. It is a triple beneficiary crop, which contains about $40 \%$ proteins, possessing high level of essential amino acids except methionine and cystine, $20 \%$ oil rich in poly unsaturated fatty acids specially omega- 6 and omega- 3 fatty acids, $6-7 \%$ total minerals, $5-6 \%$ crude fibre and $17-19 \%$ carbohydrates (Chauhan et al., 1988). Besides, it has good amount of iron, vitamin B-complex and isoflavones such as daidzein, genistein of glycitin. Variability in base population becomes essential when breeding objectives are more complex. Main interests of a plant breeder are quantitative traits, which are controlled by polygenic interactions.

Induced mutagenesis thus seems to be an ideal methodology for the induction of desirable genetic variability. The present study was undertaken to evaluate the extent of 
genetic variability for the ten quantitative traits of soybean following mutagenesis with gamma rays ethyl methane sulphonate (EMS).

\section{Materials and Methods}

Dry seeds of two Soybean (Glycine max (L.) Merrill) cultivars, viz., MAUS-47 and JS-9752 , along with their $\mathrm{F}_{1}$ hybrid (MAUS-47 $\mathrm{x}$ JS-97-52) were treated separately with the gamma rays to 10,20 and $30 \mathrm{kR}$ dose of gamma rays $\left(\mathrm{CO}^{60}\right)$ with a dose rate of 2.39 $\mathrm{kR}$ per minute at Nuclear and Agriculture Division, B. A. R. C. Trombay, Mumbai-400 085 and the same number of untreated seeds of each varieties served as control.

\section{Method of preparation of chemical mutation}

The specificity of action of chemical mutagen depends upon particular condition of treatments, the more important of which are temperature and hydrogen ion concentration. In the course of present study, ethyl methane sulphonate solution was prepared by dissolving appropriate quantity of this chemical in phosphate buffer having a $\mathrm{pH}$ of 7.0 and final $\mathrm{pH}$ adjusted to 7.0 by adding few drops of normal $\mathrm{NaOH}$. Ten normal looking plants from each treatments in $\mathrm{M}_{1}$ were selected randomly to raise $\mathrm{M}_{2}$ generation. From these, 50 plants per replication were raised in a randomized block design with three replication for each treatment in $\mathrm{M}_{2}$ generation. Normal cultural practices were carefully screened for chlorophyll and morphological mutations. Mutation frequency was calculated as percentage of $\mathrm{M}_{2}$ plants.

\section{Results and Discussion}

\section{Mutagenic sensitivity in $M_{1}$ and $F_{1} M_{1}$ generation}

The effect of gamma rays and ethyl methane sulphonate (EMS) on germination in two varieties along with $\mathrm{F}_{1}$ of soybean was studied during $\mathrm{M}_{1}, \mathrm{~F}_{1} \mathrm{M}_{1}$, and $\mathrm{M}_{2}, \mathrm{~F}_{2} \mathrm{M}_{2}$ generations and results are presented in Table 1 and 2 . The data revealed that the germination of JS 97-52 in $M_{1}$ generation was reduced in all the mutagenic treatment. The maximum reduction in germination was observed in EMS followed by gamma rays dose. EMS concentration 0.8 per cent recorded the lowest germination (37.52 per cent) followed by 30 kR gamma rays dose. The highest germination per cent (66.94 per cent) was observed in 0.4 per cent EMS followed by 10 $\mathrm{kR}$ gamma rays (65.64 per cent). The effect of different mutagenic treatments on germination in variety MAUS-47 was studied and it was observed that, the lowest germination of 39.52 per cent was recorded in 0.8 per cent EMS concentration and $10 \mathrm{kR}$ gamma rays recorded the highest germination (66.20 per cent).

In JS 97-52 x MAUS-47 population the effect of different mutagenic treatments was evaluated and it was observed that, amongst the mutagens, 0.8 per cent ethylmethane sulphonate recorded the lowest germination (40.20 per cent) and $10 \mathrm{kR}$ gamma rays recorded the highest germination (68.59 per cent). Amongst the all three population the highest germination (68.59 per cent) was observed in $10 \mathrm{kR}$ in JS 97-52 x MAUS-47 population and lowest (40.56 per cent) in 30 $\mathrm{kR}$ in case of MAUS-47 genotype with gamma irradiation. In EMS treatments, highest germination (66.94 per cent) was noticed with 0.4 per cent and lowest (37.52 per cent) in 0.8 per cent in case of JS 97-52. Among the populations, MAUS-47 was sensitive than JS 97-52 and JS 97-52 $x$ MAUS-47 for both the mutagens. The germination percentage in JS 97-52, MAUS47 and JS 97-52 x MAUS-47 populations was also studied during $\mathrm{M}_{2}$ and $\mathrm{F}_{2} \mathrm{M}_{2}$ generations and it was observed that as the dose or concentration increased the germination was more pronounced in gamma rays doses. 
Similar types of results have been reported by Basavaraja (2002), Maheshwari et al., (2003), Nandanwar et al., (2005), Patil (2006), Patil and Wakode (2011) and Satpute and Fultambkar (2012) in soybean,

Survival of plants decreased with an increase in dose or concentrations of gamma rays and EMS in $\mathrm{M}_{1}, \quad \mathrm{~F}_{1} \mathrm{M}_{1}$ and $\mathrm{M}_{2}, \quad \mathrm{~F}_{2} \mathrm{M}_{2} \quad \mathrm{M}_{3}$ generation. In general, gamma rays were less drastic than EMS treatments in reducing the survival percentage. The maximum survival in $\mathrm{M}_{1}, \mathrm{~F}_{1} \mathrm{M}_{1}$ generation was obtained in $10 \mathrm{kR}$ gamma rays (63.49 per cent) in JS 97-52 x MAUS-47 population, 62.00 per cent in JS 97-52 population and 61.82 per cent in MAUS-47 population respectively.

The minimum survival was obtained 0.8 per cent EMS dose (32.27 per cent) in JS 97-52 x MAUS-47 populations, 37.91 per cent in JS 97-52 population and 39.52 per cent in MAUS-47 population respectively. The present findings in respect of dose dependent reduction in survival, mutagen differences and differential response of populations to mutagens are in conformity with the earlier reports of Wakode et al., (2000), Uma (2001), Pavadai and Dhanvel (2005), Girija and Dhanavel (2009), Satpute (2009), Sagade and Apparao (2011), Hoa and Giang (2012) and Sangle and Kothekar (2013).

\section{Characters means}

The mean values for ten characters under study are presented in Table 3 . It is clear from this table that the character plant height ranged from $28.23 \mathrm{~cm}$ to $69.03 \mathrm{~cm}$ and mean of $43.78 \mathrm{~cm}$. was recorded for plant height. Significant superiority of these treatments against control JS 97-52 was observed. In MAUS-47, $20 \mathrm{kR}$ gamma rays dose observed tallest $(51.40 \mathrm{~cm})$ and $0.8 \%$ EMS treatments found dwarf $(31.77 \mathrm{~cm})$ and both are significantly superior over control MAUS-47.
Whereas, $20 \mathrm{kR}$ gamma rays $(48.05 \mathrm{~cm})$ recorded tallest and $0.8 \%$ EMS treatment found dwarf $(28.23 \mathrm{~cm})$ and both are significantly superior as compared to control JS 97-52 x MAUS-47 $(46.57 \mathrm{~cm})$.

The range of number of branches plant ${ }^{-1}$ varied from 3.40 to 8.96 . The mean 6.44 was recorded for number of branches plant ${ }^{-1}$. The highest number of branches was produced in $0.6 \%$ EMS (8.96) and lowest in 0.4\% EMS (5.91) as amongst control JS 97-52. While in MAUS-47, $0.8 \%$ EMS recorded highest number of branches (6.75) followed by $30 \mathrm{kR}$ gamma rays (6.61) and these treatments showed significant increase in number of branches plant ${ }^{-1}$ over control JS 97-52 (4.32). In JS 97-52 x MAUS-47 recorded highest number of branches was produced in $0.8 \%$ EMS (8.52) and lowest in $20 \mathrm{kR}$ gamma rays (5.54) as amongst control JS 97-52 x MAUS47 (6.55).

The range of number of pods plant ${ }^{-1}$ varied from 45.11 to 91.32 and the mean performance was 67.73 recorded. The highest number of pods plant ${ }^{-1}$ observed in $0.8 \%$ EMS (68.19) followed by $20 \mathrm{kR}$ gamma rays (60.65). These treatments found significant increase in number of pods plant ${ }^{-1}$ than the control (45.11) in JS-97-52. Whereas, the 10 $\mathrm{kR}$ gamma rays (76.03) recorded maximum pods followed by $20 \mathrm{kR}$ gamma rays (71.82) and were found significantly increase in number of pods plant ${ }^{-1}$ over control MAUS-47 (61.10). While in JS 97-52 x MAUS-47, the treatments $0.4 \%$ EMS (91.32) followed by 30 $\mathrm{kR}$ gamma rays (89.10) were found highest and significantly increase in number of pods plant $^{-1}$ amongst control JS 97-52 x MAUS-47 (51.70). The character length of pod ranged from 3.48 to $4.35 \mathrm{~cm}$. with mean $3.99 \mathrm{~cm}$. The treatment $10 \mathrm{kR}$ gamma rays $(4.04 \mathrm{~cm})$ recorded highest length of pod followed $0.6 \%$ EMS as against control JS 97-52 $(3.90 \mathrm{~cm})$ and the significant superiority of these 
treatments observed as against control JS $97-$ 52.

The length of pods was found to be increased in $0.6 \%$ EMS $(4.31 \mathrm{~cm})$ followed by $0.8 \%$ EMS $(4.11 \mathrm{~cm})$ and $10 \mathrm{kR}$ gamma rays $(4.09$ $\mathrm{cm})$. All these treatments showed significant superiority than their control MAUS-47 (4.27). However in JS 97-52 x MAUS-47, the $0.8 \%$ EMS $(4.35 \mathrm{~cm})$ recorded highest length of pod followed by $30 \mathrm{kR}$ gamma rays (4.28 $\mathrm{cm})$ and the significant superiority of these treatments observed as against control. The character pod weight varied from 12.62 to $27.85 \mathrm{~g}$. The mean recorded for pod weight was $21.13 \mathrm{~g}$, the treatments $0.8 \%$ EMS (23.64 g) was found significantly superior than their control JS 97-52 (17.42 g). While in other MAUS-47, the treatment $20 \mathrm{kR}$ gamma rays $(23.30 \mathrm{~g}), 0.6 \%$ EMS (22.11 g) observed superior over control MAUS-47 (20.73 g). However in JS 97-52 x MAUS-47, the $0.4 \%$ EMS (27.85 g) recorded highest pod weight followed by $30 \mathrm{kR}$ gamma rays $(26.53 \mathrm{~g})$ and the significant superiority of these treatments observed as against control of JS 97-52 x MAUS-47 (18.91 g).

Table 3 revealed that number of seeds plant ${ }^{-1}$ ranged from 77.36 to 203.98 seeds plant $^{-1}$ with mean performance 140.47 seeds. The highest mean for number of seeds plant ${ }^{-1}$ was found in $0.8 \%$ EMS (144.25) and found significant superior than control JS 97-52. While in MAUS-47, the treatments $10 \mathrm{kR}$ gamma rays (157.12), followed by $0.8 \%$ EMS (145.53) and $20 \mathrm{kR}$ gamma rays (145.04) observed maximum seeds plant ${ }^{-1}$ and also significantly superior as compared to the control MAUS-47 (126.83). In JS 97-52 x MAUS-47, the $0.4 \%$ EMS (203.98) was found highest seeds plant ${ }^{-1}$ followed by $30 \mathrm{kR}$ gamma rays (182.87) and the significant superiority of these treatments recorded as compared to control of JS 97-52 x MAUS-47. As indicated in Table 3, the character 100 seed weight ranged from 10.39 to $11.84 \mathrm{~g}$ with mean $11.21 \mathrm{~g}$. the maximum 100 seed weight with significant superior treatments, were observed as $30 \mathrm{kR}$ gamma rays (11.29 g), $10 \mathrm{kR}$ gamma rays (11.26 g) and $0.8 \%$ EMS (11.18 g) over control JS 97-52 (10.39 g). In other MAUS-47, 0.6\% EMS (11.84 g) and $20 \mathrm{kR}$ gamma rays (11.83 $\mathrm{g}$ ) recorded the highest means and found significant superior as compared to the control (11.41 g). While in JS 97-52 x MAUS-47, $10 \mathrm{kR}$ gamma rays $(11.84 \mathrm{~g})$ and $0.6 \%$ EMS (11.75 g) over control JS 97-52 x MAUS-47 (11.11 g). The character biomass plant ${ }^{-1}$ varied from 30.01 to $47.27 \mathrm{~g}$ the mean performance for biomass plant $^{-1}$ was 38.47 the maximum biomass plant $^{-1}$ with significant superior treatments, were observed as $0.6 \%$ EMS (47.27 g) and $0.8 \%$ EMS (46.00 g) over control JS 97-52 $(34.25 \mathrm{~g})$. Whereas in MAUS-47, the treatments $0.6 \%$ EMS $(39.08 \mathrm{~g})$ treatment recorded highest significant superior biomass plant $^{-1}$ over control JS 97-52 (33.02 g), and in JS 97-52 x MAUS-47, only 0.4\% EMS (46.75 g) observed highest biomass plant ${ }^{-1}$ and also significantly superior as compared to the control JS 97-52 x MAUS-47 (34.64 g).

The harvest index range from 25.14 to 53.12 per cent with mean 41.75 per cent. None of the treatments was induced highest percentage than the control JS-97-52 (37.40\%). The treatment $20 \mathrm{kR}$ gamma rays (49.41\%) recorded highest harvest index followed by 10 $\mathrm{kR}$ gamma rays $(48.75 \%)$ as against control MAUS-47 (44.35\%) and the significant superior of these treatments observed as compared to control MAUS-47. Whereas in JS 97-52 x MAUS-47, the treatments $0.6 \%$ EMS $(53.12 \%)$ followed by $30 \mathrm{kR}$ gamma rays $(51.85 \%)$ were found highest and significantly increase in harvest index amongst control JS 97-52 x MAUS-47 $(36.31 \%)$. 
Table.1 Effect of different mutagens on germination, survival and pollen sterility in homozygous and heterozygous populations in $\mathrm{M}_{1}$ and $\mathrm{F}_{1} \mathrm{M}_{1}$ generation in soybean

\begin{tabular}{|c|c|c|c|c|c|c|c|c|c|c|}
\hline \multirow{2}{*}{$\begin{array}{l}\text { Sr. } \\
\text { No. }\end{array}$} & \multirow{2}{*}{$\begin{array}{l}\text { Treatment/ } \\
\text { Mutation }\end{array}$} & \multicolumn{3}{|c|}{ JS 97-52 } & \multicolumn{3}{|c|}{ MAUS - 47} & \multicolumn{3}{|c|}{ JS 97-52 x MAUS-47 } \\
\hline & & $\begin{array}{c}\text { Germination } \\
(\%)\end{array}$ & $\begin{array}{c}\text { Survival } \\
(\%)\end{array}$ & $\begin{array}{c}\text { Pollen } \\
\text { sterility } \\
(\%)\end{array}$ & $\begin{array}{c}\text { Germination } \\
(\%)\end{array}$ & $\begin{array}{l}\text { Survival } \\
(\%)\end{array}$ & $\begin{array}{c}\text { Pollen } \\
\text { sterility } \\
(\%)\end{array}$ & $\begin{array}{c}\text { Germination } \\
(\%)\end{array}$ & $\begin{array}{l}\text { Survival } \\
(\%)\end{array}$ & $\begin{array}{c}\text { Pollen } \\
\text { sterility } \\
(\%)\end{array}$ \\
\hline \multicolumn{11}{|c|}{ Gamma rays } \\
\hline 1 & $10 \mathrm{kR}$ & 65.64 & 62.00 & 15.66 & 66.20 & 61.82 & 15.53 & 68.59 & 63.49 & 13.31 \\
\hline 2 & $20 \mathrm{kR}$ & 55.96 & 51.78 & 20.83 & 48.8 & 42.61 & 18.28 & 58.19 & 50.79 & 18.36 \\
\hline 3 & $30 \mathrm{kR}$ & 45.38 & 43.81 & 24.03 & 40.56 & 37.08 & 26.58 & 46.55 & 41.27 & 20.81 \\
\hline 4 & Dry control & 93.70 & 88.16 & 6.22 & 94.64 & 87.19 & 4.27 & 90.87 & 82.53 & 4.52 \\
\hline \multicolumn{11}{|c|}{ EMS } \\
\hline 1 & $0.4 \%$ & 66.94 & 60.67 & 13.28 & 59.37 & 52.43 & 10.50 & 57.10 & 53.17 & 11.68 \\
\hline 2 & $0.6 \%$ & 51.78 & 44.00 & 16.37 & 49.99 & 44.09 & 15.49 & 42.88 & 41.09 & 14.04 \\
\hline 3 & $0.8 \%$ & 37.52 & 37.91 & 25.71 & 39.52 & 36.92 & 26.09 & 40.20 & 32.27 & 24.43 \\
\hline 4 & Wet control & 94.70 & 85.79 & 6.49 & 94.67 & 90.02 & 5.36 & 92.12 & 86.37 & 3.86 \\
\hline
\end{tabular}

Table.2 Effect of different mutagens on germination and survival in homozygous and heterozygous populations in $\mathrm{M}_{2}$ and $\mathrm{F}_{2} \mathrm{M}_{2}$ generation in soybean

\begin{tabular}{|c|c|c|c|c|c|c|c|}
\hline \multirow[t]{2}{*}{ Sr. No. } & \multirow{2}{*}{$\begin{array}{l}\text { Treatment/ } \\
\text { Mutation }\end{array}$} & \multicolumn{2}{|l|}{ JS 97-52 } & \multicolumn{2}{|l|}{ MAUS-47 } & \multicolumn{2}{|c|}{ JS 97-52 x MAUS-47 } \\
\hline & & $\begin{array}{c}\text { Germination } \\
(\%)\end{array}$ & Survival (\%) & $\begin{array}{c}\text { Germination } \\
(\%)\end{array}$ & Survival (\%) & $\begin{array}{c}\text { Germination } \\
(\%)\end{array}$ & Survival $(\%)$ \\
\hline \multicolumn{8}{|c|}{ Gamma rays } \\
\hline 1 & $10 \mathrm{kR}$ & 90.37 & 85.51 & 89.28 & 86.71 & 92.16 & 86.13 \\
\hline 2 & $20 \mathrm{kR}$ & 85.92 & 82.68 & 86.64 & 84.98 & 91.28 & 83.47 \\
\hline 3 & $30 \mathrm{kR}$ & 81.03 & 74.92 & 82.03 & 75.63 & 87.92 & 76.87 \\
\hline 4 & Dry control & 94.16 & 88.23 & 93.86 & 88.49 & 94.13 & 88.65 \\
\hline \multicolumn{8}{|l|}{ EMS } \\
\hline 1 & $0.4 \%$ & 90.23 & 82.63 & 90.19 & 85.19 & 90.31 & 83.97 \\
\hline 2 & $0.6 \%$ & 82.47 & 79.89 & 86.09 & 82.56 & 87.94 & 80.64 \\
\hline 3 & $0.8 \%$ & 77.10 & 71.13 & 80.79 & 72.47 & 80.11 & 74.22 \\
\hline 4 & Wet control & 95.21 & 91.03 & 94.35 & 89.86 & 95.79 & 92.05 \\
\hline
\end{tabular}


Table.3 Mean for ten characters and control in soybean

\begin{tabular}{|c|c|c|c|c|c|c|c|c|c|c|c|}
\hline $\begin{array}{l}\text { Sr. } \\
\text { No. }\end{array}$ & Characters /Treatments & $\begin{array}{c}\text { Plant } \\
\text { height } \\
\text { (cm) }\end{array}$ & $\begin{array}{c}\text { No. of } \\
\text { branches } \\
\text { plant }^{-1}\end{array}$ & $\begin{array}{c}\text { No. of } \\
\text { pods plant }\end{array}$ & $\begin{array}{c}\text { Pod } \\
\text { length }(\mathrm{cm})\end{array}$ & $\begin{array}{l}\text { Pod weight } \\
\text { plant }^{-1}(g)\end{array}$ & $\begin{array}{c}\text { No. of } \\
\text { seeds } \\
\text { plant }^{-1}\end{array}$ & $\begin{array}{c}100 \text { seed } \\
\text { weight }(g)\end{array}$ & $\begin{array}{c}\text { Biomass } \\
\text { plant }^{-1}(g)\end{array}$ & $\begin{array}{c}\text { Harvest } \\
\text { index }\end{array}$ & $\begin{array}{l}\text { Seed yield } \\
\text { plant }^{-1}(\mathrm{~g})\end{array}$ \\
\hline \multicolumn{12}{|c|}{ JS 97-52 } \\
\hline 1 & Gamma $10 \mathrm{kR}$ & 69.03 & 8.10 & 59.30 & 4.04 & 18.25 & 121.63 & 11.26 & 41.06 & 34.22 & 13.66 \\
\hline 2 & Gamma 20 kR & 51.46 & 7.46 & 60.65 & 3.88 & 18.39 & 119.88 & 10.69 & 39.46 & 35.31 & 13.62 \\
\hline 3 & Gamma $30 \mathrm{kR}$ & 46.34 & 7.40 & 52.33 & 3.59 & 16.67 & 108.61 & 11.29 & 42.89 & 28.45 & 12.13 \\
\hline 4 & EMS $0.4 \%$ & 61.90 & 5.91 & 45.42 & 3.80 & 12.62 & 77.36 & 11.02 & 33.90 & 25.14 & 8.48 \\
\hline 5 & EMS $0.6 \%$ & 38.80 & 8.96 & 59.68 & 3.48 & 19.59 & 130.09 & 10.68 & 47.27 & 30.63 & 14.19 \\
\hline 6 & EMS $0.8 \%$ & 43.69 & 7.33 & 68.19 & 4.00 & 23.64 & 144.25 & 11.18 & 46.00 & 35.31 & 16.04 \\
\hline 7 & Control & 60.36 & 6.33 & 45.11 & 3.90 & 17.42 & 104.51 & 10.39 & 34.25 & 37.40 & 12.51 \\
\hline \multicolumn{12}{|c|}{ MAUS-47 } \\
\hline 8 & Gamma $10 \mathrm{kR}$ & 38.50 & 5.14 & 76.03 & 4.09 & 21.86 & 157.12 & 10.78 & 34.76 & 48.75 & 16.35 \\
\hline 9 & Gamma $20 \mathrm{kR}$ & 51.40 & 5.08 & 71.82 & 4.02 & 23.30 & 145.04 & 11.83 & 36.21 & 49.41 & 17.26 \\
\hline 10 & Gamma $30 \mathrm{kR}$ & 45.07 & 6.61 & 65.71 & 3.63 & 20.06 & 131.47 & 10.88 & 30.01 & 46.92 & 13.86 \\
\hline 11 & EMS $0.4 \%$ & 39.62 & 5.31 & 55.00 & 3.91 & 18.15 & 111.59 & 11.13 & 30.12 & 43.79 & 12.53 \\
\hline 12 & EMS $0.6 \%$ & 43.77 & 3.40 & 60.90 & 4.31 & 22.11 & 135.59 & 11.84 & 39.08 & 42.23 & 16.12 \\
\hline 13 & EMS $0.8 \%$ & 31.77 & 6.75 & 70.75 & 4.11 & 21.80 & 145.53 & 11.50 & 37.91 & 42.93 & 16.18 \\
\hline 14 & Control & 31.77 & 4.32 & 61.10 & 4.27 & 20.73 & 126.83 & 11.41 & 33.02 & 44.35 & 14.47 \\
\hline \multicolumn{12}{|c|}{ JS 97-52 X MAUS-47 } \\
\hline 15 & Gamma 10 kR & 33.87 & 6.76 & 84.50 & 4.13 & 25.05 & 179.06 & 11.84 & 41.27 & 50.76 & 19.67 \\
\hline 16 & Gamma 20 kR & 48.05 & 5.54 & 81.30 & 3.87 & 22.87 & 166.56 & 10.98 & 40.61 & 44.98 & 17.79 \\
\hline 17 & Gamma 30 kR & 28.40 & 7.16 & 89.10 & 4.28 & 26.53 & 182.87 & 11.47 & 40.47 & 51.85 & 20.45 \\
\hline 18 & EMS $0.4 \%$ & 42.50 & 5.00 & 91.32 & 3.94 & 27.85 & 203.98 & 11.36 & 46.75 & 46.46 & 20.97 \\
\hline 19 & EMS $0.6 \%$ & 38.26 & 7.66 & 87.27 & 4.24 & 24.32 & 173.91 & 11.75 & 39.62 & 53.12 & 19.81 \\
\hline 20 & EMS $0.8 \%$ & 28.23 & 8.52 & 85.16 & 4.35 & 23.58 & 170.43 & 11.06 & 38.64 & 48.49 & 18.46 \\
\hline \multirow[t]{3}{*}{21} & Control & 46.57 & 6.55 & 51.70 & 4.04 & 18.91 & 113.60 & 11.11 & 34.64 & 36.31 & 13.80 \\
\hline & S.E. $(\mathrm{m}) \pm$ & 0.28 & 0.10 & 0.40 & 0.01 & 0.17 & 0.44 & 0.07 & 0.31 & 0.36 & 0.12 \\
\hline & CD at $5 \%$ & 0.82 & 0.31 & 1.17 & 0.04 & 0.50 & 1.22 & 0.20 & 0.90 & 1.05 & 0.36 \\
\hline
\end{tabular}


The character seed yield plant ${ }^{-1}$ ranged from 8.48 to $20.97 \mathrm{~g}$. average for seed yield plant $^{-1}$ was $15.57 \mathrm{~g}$. The highest mean for seed yield plant $^{-1}$ was found in treatments $0.6 \%$ EMS $(16.04 \mathrm{~g})$. These treatments also showed significant superiorly over the control JS 9752 (12.51g). In MAUS-47 populations, the treatments $20 \mathrm{kR}$ gamma rays (17.26 g) and $10 \mathrm{kR}$ gamma rays (16.35 g) recorded highest significant superior means for seed yield plant $^{-1}$ as against the control MAUS-47 (14.47 g). Whereas in JS 97-52 x MAUS-47, the treatments $0.4 \%$ EMS (20.97 g) followed by $30 \mathrm{kR}$ gamma rays $(20.45 \mathrm{~g})$ and $0.4 \%$ EMS (19.81 g) observed maximum seeds yield plant $^{-1}$ and also significantly superior as compared to the control JS 97-52 x MAUS-47 (13.80 g).

\section{References}

Basavaraja, G.T. (2002): Studies on induced mutagenesis in soybean (Glycine $\max (\mathrm{L}$.) Merill). Ph.D. Thesis unpub. Univ. Agril. Sci. Dharwad.

Girija, M. and D. Dhanavel (2009). Mutagenic effectiveness and efficiency of gamma rays, ethyl methane sulphonate and their combination treatments in cowpea (Vigna unguiculata L. Walp.). Global J. Mol. Sci. 4(2): 68-75.

Hoa, V.D. and N.V. Giang (2012). Mutagenic induction of agronomical and yield contributing traits in soybean (Glycine max (L.) Merill.) with gamma irradiation. J. Sci. Devel. 10(4): 576-585.

Maheshwari, J.J., V.J. Dhole, S. Patil and D.R. Rathod (2003). Radiation induced variability for quantitative characters in soybean. J. Soils and Crops. 13(2): 314-316.

Nandanwar, R.S., P.Y. Sontake and D.T. Dhule
(2005): Radiation induced mutagenesis in soybean (Glycine max. (L.) Merill). In. Abst $4^{\text {th }}$ Inter. Food Legume Res. Conference, 1822, Oct. New Delhi, pp.186.

Patil, A.N. (2006). Studies on the effect of physical and chemical mutagens on some quantitative and qualitative parameters in soybean (Glycine max. (L.) Merill). Ph.D. Thesis unpub. Dr.PDKV, Akola.

Patil, G.P. and M.M. Wakode (2011). Effect of physical and chemical mutagens on soybean. Current Bot. 2(4): 12-14.

Pavadai, P. and D. Dhanvel (2005). Effect of gamma-rays on yield and its components in soybean (Glycine max. (L.) Merill) Var Co-1. Crop Res. 30(3): 459-461.

Sagade, A.B. and B.J. Apparao (2011). $\mathbf{M}_{1}$ generation studies in urdbean (Vigna munga (L.) Hepper). Asian J. Biol. Sci. 2(2): 372375.

Sangale, S.M. and V.S. Kothekar (2013). Induced mutational studies in $\mathrm{M}_{1}$ generation of Pigeonpea. Bioinfolet, 10(3B): 1026-1031.

Satpute, R.A. (2009). Studies on mutagenic effectiveness and efficiency of gamma rays in lentil. Bioinfolet, 6(2): 161-164.

Satpute, R.A. and R.V. Fultambkar (2012). Effect of mutagenesis on germination, survival and pollen sterility in $\mathbf{M}_{1}$ generation of soybean (Glycine max (L.) Merill). Internat. J. Resent Trends in Sci. Tech. 2(3): 30-32.

Uma, M.S. (2001). Combing induced and recombination variability for improving productivity of cowpea (Vigna unguiculata (L.) Walp.). Ph.D. Thesis unpub. Univ. Agril. Sci. Dharwad.

Wakode, M.M., R.S. Nandanwar and G.P. Patil (2000): Radiation induced mutagenesis in soybean (Glycine max (L.) Merill) In: Proc. DAE-BRNS symp. On the use of Nuclear and Molecular Tech. in crop Improv. 6-8 Dec. BARC Mumbai pp. 111-116.

\section{How to cite this article:}

Kalpande, H. V., S. B. Borgaonkar and Chavan, S. K. 2020. Mutagenic Induction of Yield Contributing Traits in of Soybean (Glycine max (L.) Merrill) with Gamma Irradiation and EMS. Int.J.Curr.Microbiol.App.Sci. 9(06): 3057-3063.

doi: https://doi.org/10.20546/ijcmas.2020.906.367 